\title{
The African warlord revisited
}

\section{Laura Freeman}

To cite this article: Laura Freeman (2015) The African warlord revisited, Small Wars \& Insurgencies, 26:5, 790-810, DOI: 10.1080/09592318.2015.1072318

To link to this article: http://dx.doi.org/10.1080/09592318.2015.1072318

\section{(c) 2015 The Author(s). Published by Taylor \& Francis.}

Published online: 08 Nov 2015.

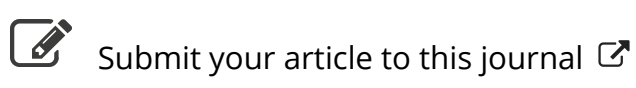

Q View related articles $\sqsubset$

View Crossmark data $\asymp$ 


\title{
RESEARCH ARTICLE
}

\section{The African warlord revisited}

\author{
Laura Freeman* \\ Safety and Violence Initiative, University of Cape Town, South Africa
}

(Received 6 October 2014; accepted 25 February 2015)

\begin{abstract}
To date, warlordism in Africa has been viewed solely negatively. This has come about, in part, because of the analytical lenses that have been used. Typically, warlordism has been examined at the state level; and behavioural traits, rather than definitionally necessary components, have been the focus. In effect, 'warlord' has been confused with other violent actors. I suggest here a reconceptualisation 'from below', which takes into account variation in types of warlordism, and which allows for both positive and negative effects of warlordism on society and the state.
\end{abstract}

Keywords: warlord; warlordism; Africa; rebellion; violence; weak state; governance

In 1989, in a special issue of the Review of African Political Economy, an academic consensus was established that the term 'warlord' was useful in the African context. ${ }^{1}$ From the issue flowed a surge of scholarly interest and empirical study of warlordism that lasted through the 1990s and into the 2000s. 'Warlords' were seen everywhere - from Mogadishu-based 'General' Aideed, to Liberian rebel-cum-president Charles Taylor, to Joseph Kony and his Lord's Resistance Army (LRA) in Uganda, to Inkatha leaders in the Natal region of South Africa, to Foday Sankoh of the Revolutionary United Front (RUF) in Sierra Leone. And yet now, with some form of war or political violence in half of Africa's states, we might ask: where are all the warlords? The use of the term to apply to actors of contemporary war and violence seems to have vanished.

I argue here that this has occurred not because there are no longer cases of warlordism in Africa, but because certain conceptual problems have been created around the African warlord. The conceptualisation that was generated in the 1990s tended to be focused on high-level, infamous characters. This top-down approach concentrated on the warlord or rebel leaders themselves, and generally only included those who had the capacity to directly challenge state power, be it through circumstances or political ambition. From this arose a static and indeterminate view of the African warlord. Actors - both individuals and

\footnotetext{
*Email: laura.emily.freeman@gmail.com 
groups - as widely divergent as Charles Taylor, the LRA, and 'General' Aideed all became designated 'warlord'. If a rebel actor who becomes president of one country and aided rebels in another; a group who have sought (and failed) for decades to overthrow a government from both within the state and across borders; and a man and his ill-trained militia in a capital city who have no aspiration to government position can all be termed 'warlord', what is it actually to be an African warlord?

The vagueness that came to develop around the warlord occurred because the term was (and still to this day is) being used to reflect certain political and violent behaviour rather than certain definitional traits. In effect, all actors in African wars who are seen to lack popular support, use excessively cruel forms of violence, and who operate outwith the state are liable to be assigned 'warlords'. Of course, the loose application of 'warlord' in Africa has been noted, and there is broad agreement that much of the use of the term lacks analytic value because it is used to describe a multitude of non-state violent actors. ${ }^{2}$ Over time, 'warlord' has evolved to apply to prominent groups, as defined by clan, tribe, ethnicity, or religion, who use armed civilian followers to execute their policies and ambitions. ${ }^{3}$ During civil wars the term 'warlord' is 'most loosely used to identify potentially any armed protagonist whatever their motivation'. 4

In effect, the warlord in Africa came to be presented in a solely negative light. From feudal Europe to republican China, warlordism is a long-standing and historicised phenomenon; and warlords have been seen as part and parcel of state formation. In medieval Europe, warlords - or feudal lords - are viewed as a necessary part of state development (as Tilly says, 'war made the state and the state made war'). ${ }^{5}$ In China, warlords surfaced as the imperial dynasty collapsed, and they were viewed as, at least partly, legitimate in their use of conventional force and the loyalty they created in their locale. ${ }^{6}$ In contemporary literature, while warlords of the Middle East and Asia are seen to both cause problems and pose certain positive solutions, ${ }^{7}$ research on the African warlord has remained prodigiously negative. Warlords in Africa are colourfully typified as 'unattractive and shadowy figures', 'worms in the entrails of a natural man', as 'no more than ... entrepreneur[s] of conflict', and as 'the hyena of the conflict zone'. ${ }^{8}$ Scholars depict warlords as self-interested actors out for their own wealth and power, and as thugs who engage in arbitrary violence against those under their control. Together, these kinds of classifications have resulted in the use of the term 'warlord' becoming too broad and ambiguous, often blurring the lines between warlords and other rebel (and even state) actors. Indeed, 'warlord' has been ascribed to a range of sub-state actors who exercise power outwith internationally accepted, Westphalian norms. Warlords are the archetypal illegitimate agents of violence as generated by the 'new wars' thesis. In political analyses, where the state is the dominant (and legitimate) unit of analysis, warlords are seen to unhelpfully fragment the state and cause the disintegration of society. However, in light of the weakness of some African states and the existence of 'ungoverned spaces', these assertions seem rather too strong. 
Given the strange disappearance of the contemporary African warlord, and the static, vague and resolutely disapproving views of experiences of warlordism on the continent, I argue it is time to revisit the warlord conceptually. While attempts have been made to definitionally narrow our conception, ${ }^{9}$ much of the academic and popular literatures still utilises 'warlord' loosely. Rather, I suggest analysis of warlordism from 'below'. By looking at context and local effects, we come to see that the warlord can represent and encompass a number of things. I propose that the warlord as a concept needs to be defined by essential or necessary characteristics, as well as those that are commonly identified but not necessary. When we examine the warlord in this way, we realise that the current characterisation of the African warlord - as lacking legitimacy and using excessive violence - misses definitionally required features, such as the warlord's autonomy from the state and the need for perpetual violence to assert authority. I argue that while the dominant and disparaging assessment of the African 'warlord' may, at times, be accurate, there is greater variation and nuance within this actor of political violence. We should include a 'continuum of warlordism' in our thinking on the phenomenon, ${ }^{10}$ and, in so doing, come to recognise differing experiences and effects of warlordism. Furthermore, this approach has the benefit of recognising that warlords are not static - that they can morph into other types of actors, including rebels, politicians, freedom fighters, etc.

This article will be structured in two sections. The first will conceptualise warlordism in Africa. The second will aim to explore briefly why the African warlord has come to be seen as socially detrimental.

\section{Defining the warlord: Essential and common characteristics}

Warlords are, in many senses, lords of war. These local strongmen (and warlords are almost always men) operate in their fiefdom-like locales, autonomous from the state. And yet, by definition, warlords do not require war; they only require a political vacuum. Indeed, it may be, at times, more accurate to typify the warlord as operating under 'armed peace' rather than overt conflict. ${ }^{11}$ Warlords require the continual use or threat of violence in order to secure their military and political position. In this way, the warlord can maintain their status through relatively low quantities of violence, well below that required for a civil war. ${ }^{12}$ Nonetheless, the term 'warlord' is predominantly employed to describe actors operating within conditions of war, especially intrastate war. This is the first of many conceptual ambiguities in both the academic literature and popular discourse around the warlord.

'Warlord' is commonly used to describe both the individual - the warlord and the group - the warlord organisation or militia. In this way, the entity is often referred to as a single actor - the warlord. ${ }^{13}$ I will also use the term interchangeably, with emphasis put where needed. The warlord - that is both the warlord himself and the warlord organisation - has four essential characteristics: power is centred on the warlord leader; the warlord seeks control 
over a geographic space; the warlord is independent from the state; and the warlord requires the perpetuation of violence in order to maintain power. There is one essential prerequisite: the warlord requires anarchy. In addition, there are two common characteristics of the warlord, which are often empirically noted, but are not required for a group or individual to be defined 'warlord'. The warlord is often associated with a lack of popular legitimacy or support, and with using barbaric violence. As we will later show, these common elements not the essential characteristics - have come to be the means by which the African warlord is currently defined. We will now go through each of these features in turn.

\section{The necessary context: Local anarchy}

African states whose governments fail to provide public goods and services to the entire country are prone to warlordism. Put simply, the Weberian definition of the state requires it to possess a monopoly of legitimate coercive force over its territory. States must have a territory which they rule, a population whom they rule, absolute authority over that territory and population, and must exercise and regulate their power through a legal domain. ${ }^{14}$ It is important that government institutions are objective, rational, and impersonal, with a separation between politics and economics. However, a number of African states are inflicted by neopatrimonialism, corruption, criminalisation of the state, and insecurity. Typically, weak states lack presence in border regions and rural areas, which then become 'ungoverned spaces'. Without a monopoly over the use of force in these areas, and with the exclusion of certain groups from the political realm, African nations become prone to insurgent groups and conflict. Warlords are one of the groups that can emerge. They have the opportunity to emerge when structure, authority, power, law, and civil order fragments, leaving a political vacuum to be filled. In this regard, the rise of warlordism can be seen as a reflection of the problems of governance and limited state capacity in Africa. ${ }^{15}$

It is beyond the scope of this article to delve fully into the nature of the African state, but suffice to say here that warlords can only emerge in a context of anarchy. This does not require state-level anarchy, but instead can represent areas where the state, for all intents and purposes, is not present - where it is unable to provide public goods and services. Warlords are more likely to emerge where states are strongly regionalised, as a result of either complex geography, large size, or ethnic or religious composition. ${ }^{16}$ In particular, states which experience the concomitant breakdown of central authority and institutional decay of the government and fragmented or regionalised politics are likely to experience warlordism. ${ }^{17}$ Under these conditions, governments become unable to provide general protective services to isolated or marginalised populations. Peoples living in remote areas are vulnerable to security attacks and prone to support those who can offer them security. ${ }^{18}$ In this context, alternative means of politics come to develop. Where central authority is limited, weak, or has collapsed, the rise of 
warlordism can be viewed as part of a societal effort to restore stability within an anarchic environment. Thus, it may be reasonable to view the warlord as 'an anachronistic form of political authority ... prior to the state in both historical and analytical senses'. ${ }^{19}$ Warlords are a manifestation of pre-modern political formations, which become necessary in the context of anarchy.

In Africa's recent history, warlordism has emerged since the end of anticolonial movements and independence, and has become yet more prevalent since the end of the Cold War. The rise of warlordism was seen to denote the decline of ideological pleas for 'national liberation' in Africa, and the fracturing of many post-colonial 'quasi states'. ${ }^{20}$ The majority of African warlords were initially political faction leaders operating at the national level, who, excluded from the political fora, adapted their activities to focus on the locale. ${ }^{21}$ Warlords tended to emerge in the poorest and weakest states, such as Chad (especially in the 1970s), Somalia (1990s), and the Democratic Republic of Congo (1990s-2000s). After the removal of superpower interest in sub-Saharan Africa, the breakdown of the state accelerated and government rule devolved to the capital city. ${ }^{22}$ Regional political vacuums came to exist, which lead to the rise of warlords and other rebel groups. Warlordism has most commonly occurred where members of the national military or political faction leader decide to defect, move back to their locale and set up alternative power bases to the state. This typically occurs among soldiers who are frustrated with their military lives, often manifested in their failure to move up the ranks and to gain either the wealth or authority they perceive they deserve. These soldiers, often with low levels of formal education, have few alternative means of living. ${ }^{23}$ In this way, warlordism has come to exist where internal military structures and discipline have collapsed.

In summary, the weak African state, insofar as it can be generalised in this way, provides the conditions for the emergence of alternative forms of rule, especially at the subnational level. Poor state infrastructure, an inability to provide public goods and services, deficient security, and lacking military discipline causes political vacuums. This provides a context for warlordism. It enables the dissatisfied faction leader and/or soldier to become a strong military and political leader at the locale.

\section{Essential characteristics of the warlord}

The centrality of the warlord

The warlord organisation is defined by its top-heavy leadership structure. Power is focused on the warlord, who has his own private army or militia that responds to him. His personal militia can number from ten to several thousand fighters. ${ }^{24}$ The warlord achieves political power because of military power and, therefore, is both a military and political leader. Often, the warlord is a trusted and known local strongman. ${ }^{25}$ The centrality of the warlord as an individual has several effects on the nature of leadership within the warlord organisation. The warlord's leadership tends to be based on his charisma and his ability to provide patronage, 
both of which ensure loyalty from his local followers. ${ }^{26}$ The latter source of authority explains the warlord's continual need for economic spoils: the warlord becomes central to the network of resource control, and, consequently, central to the warlord organisation. Patronage networks are made up of personal ties, which generate and allocate resources according to the priorities of the warlord. The consequences of this are as much (if not more) political than they are economic. By controlling means of accumulation and distribution, warlords come to monopolise political power. ${ }^{27}$ In this way, patronage and accumulation needs to be understood as the means by which the warlord acquires political power, which is necessary for him.

The warlord as a character is so central that, if he is removed - killed, arrested, or otherwise - the warlord organisation as a whole collapses. For example, after the death of General Aideed in 1996, the organisation dismantled and other forms of governance, including the Islamic Courts, emerged in southern Mogadishu. ${ }^{28}$ And yet the warlord's position is ever-fragile. If they become too weak or too greedy, they come to undermine their power. Loyalty to warlords from their militia can weaken if the warlord becomes unable to provide material goods. ${ }^{29}$ Similarly, support from the surrounding population will diminish if he can no longer provide security, public goods, and local patronage. As Marten states, '[w]ise warlords share the wealth to maintain personal loyalty'. ${ }^{30}$ Thus, to survive, the warlord must command certain loyalties, undoubtedly from his militia and potentially from those residing in his area of control.

The source of the warlord's individual leadership is mimicked in the warlord organisation. Every member of the warlord political community is part of a military organisation, and even the economy becomes engrossed with the military. In general, this means that the military comes to impose on every aspect of political life and, in so doing, civil-military relations collapse into one. ${ }^{31}$ Through these internal structures, a 'gang mentality' forms, which can permit certain forms of gratuitous violence, particularly with competing groups. ${ }^{32}$ The warlord himself is central to these processes.

\section{Geographical control}

Second, the warlord is defined by geography. The warlord organisation seeks control over a territorial area. In general, the warlord comes to seize control over relatively small slices of land. The territorial area is typically demarcated by the groups living in it and the resources available. The warlord will seek territory with extractable 'rents', be they raw materials - diamonds, oil, timber, etc. - as well as 'taxes' that are obtained from the local population. In selecting his territorial area of control, the warlord ignores predetermined state provinces and even national borders. Rather, the warlord territory is defined by access to resources and can fluctuate somewhat on this basis. ${ }^{33}$ Similarly, the expansion or movement of warlords' 'domain of effective power' provides the context for militarism and violence. Warlords are most likely to use force - often against 
competing or neighbouring warlords - in order to retain and attain their geographical sphere of influence. ${ }^{34}$

\section{Warlord independence from the state}

Third, and relatedly, the warlord operates autonomously from the state. This does not mean that relations between the warlord and the government will not develop, where mutually beneficial. Indeed, a warlord may be a useful ally for the state, used typically to control rebel groups. ${ }^{35}$ However, it does mean that a warlord does not seek state power. If a warlord comes to have enlarged political interests - such as striving to control a whole state or establish a new state of his own - he can no longer be categorised as a warlord but becomes a prince or a president instead. ${ }^{36}$ By definition, warlords aim to prevent state consolidation in the areas in which they operate. ${ }^{37}$ As such, it is incorrect to characterise Africa's archetypal 'warlord' - Charles Taylor - as a warlord when seeking presidency in Liberia. ${ }^{38}$ Arguably, it is possible to describe Taylor as a warlord during his presidency, if one argues he chose to actively fragment state structures and came to operate outwith the state; but, if this is the case, Taylor is a highly atypical warlord. This represents a wider problem in the literature on the African warlord, where little or no distinction is made between warlords who operate outwith the state and states ruled by former warlords. ${ }^{39}$ As classically (and correctly) conceived, the warlord is independent from any higher authority and is capable of controlling territory at a local or subnational level. ${ }^{40} \mathrm{He}$ exercises effective control over his territory through his military organisation, of which he is the highest authority, and which is separate from the state. In this sense, Somalia's 'General' Aideed - a former army colonel - is a classical warlord: he sought control (against self-proclaimed 'President' Ali Mahdi Muhammad) of Mogadishu, but did not seek power beyond the capital. Aideed was able to recruit away from clan delineations in the urban setting and based his power on his ability to provide patronage to the otherwise disenfranchised mooryaan young, unemployed Somali men. ${ }^{41}$ In this regard, Aideed was a warlord; and Taylor was a rebel-cum-president who, arguably, became a 'warlord president'.

Warlords, in general, do not challenge state power, but if warlords are carrying out their operations in regions characterised by weak state power it is possible for them to challenge the state itself. ${ }^{42}$ They can transform into statemakers at the local level. In these cases, warlords' abilities to impose control over markets, power and people can outweigh those of the state. By controlling a territorial space, warlords can displace state agents and rules. However, this is not the same as the warlord seeking national political power. Rather, local rule and dislodging the state is the means by which the warlord comes to be autonomous. This is the key defining characteristic that separates warlords from other violent actors. Rebels and insurgents seek to challenge and overthrow central authority. They directly threaten and often seek state power. Warlords, on the other hand, seek control of a geographically defined area at the subnational or regional level. 
They are not politically motivated to affect national policy or to become enveloped in the state. Consequently, I argue that it is more useful to view warlordism from below, as a phenomenon that arises at the local level. The national-level focus of the 1990s, and consequent conflation of rebels (who use excessive violence) and warlords, created an atypical context from which warlordism was thought to arise.

\section{The warlord and violence}

Fourth, warlords require the frequent use of violence in order to maintain their position. As alluded to, the warlord's political power is intrinsically tied to his military capacity. Violence is used habitually to reassert the warlord's power. Inherently connected to this process is the imperative of economic access: profits are of utmost importance to all warlords for harvesting power and sustaining the warlord organisation. To gain economic access, warlords rely on violence, which is used to achieve simultaneous military, political, and economic dominance. While all warlords require the use of violence to self-sustain, the nature and extent of this violence varies considerably. The kinds of violence used depend on the local context: the type of resources the warlord seeks to access; the relationship between the warlord and the civilian population; and the military and technical capabilities of the organisation.

First, the type of resource or the nature of the warlord organisation's income affects the type and levels of violence. The warlord may seek control over resources or they may rely on local rents or taxes from the local population. Where some may have a monopoly over easily extractable or lootable resources, such as surface minerals and timber, others may aim to control unlootable resources, such as deep-shaft mines, which require more sophisticated extractive technologies. ${ }^{43}$ The type of resource the warlord seeks depends on their broader capabilities. Warlord organisations that are more complex, sophisticated, and far reaching tend to develop more extensive extractive capabilities. Naturally, the location, density, and type of resource dictate the types of violence that are required to control it successfully. This may vary from overtaking and guarding a fixed area - in the case of mining - or disrupting local populations in order to access ground resources.

In connection, the warlord's commercial market access is of relevance. The potential for economic success is amplified by modern technology: 'the warlord in the war zone in [Congo] is only a phone call away from the broker in Wall Street'. ${ }^{44}$ The connection of the African warlord to international markets has both changed the necessary relation of the warlord to the locale and affected their violent behaviour. On the one hand, modern networks of (often-illicit) trade tremendously increase the warlord's ability to remain both isolated from the state and internationally connected and prosperous. ${ }^{45}$ On the other hand, they also mean that the warlord must actually ensure stability in their locale. Violence ensures control and a means of maintaining stability; but, in general, this means the 
warlord has no appetite for fully fledged war or open combat. ${ }^{46}$ Seeing as violence is likely to reduce production levels, warlords operating in 'armed peace' conditions where they threaten violence but do not enact it on a large scale - are likely to accrue greater rents. ${ }^{47}$ In effect, violence becomes limited.

Second, the extent of the warlord's violence depends on the nature of their interaction with the local population. Warlords may come to establish contractual relations with the people in their territory. Warlords may demand labour, livestock and crops, tools and machinery, as well as taxes and military service (including participation in raids, defending sites and assets, etc.). In return, they may supply public and private goods, including education, infrastructure and roads, transport, protection, food and shelter. This transactional relationship mimics that between government and citizens. Thus the warlord can transform his territory into a type of civilian administration or 'protostate', 'quasi-government', and/or 'embryonic state'. ${ }^{48}$ In particular, producers utilise warlord protection in order to ensure the continuation of production. From the output, warlords extract rents. ${ }^{49}$ Only more sophisticated warlord organisations are able to transform their territory into a protostate and, in so doing, develop a form of partial legitimacy. ${ }^{50}$ Relatedly, warlord violence can vary according to competition levels for taxes and rents. Contending warlords are likely to engage in violence in order to either preserve or extend their spheres of influence; and the concentration of rents themselves is likely to influence the levels of competition. ${ }^{51}$

Third, levels of warlord violence depend on military and technological capabilities. Conceptually, methods of violence can fit along much of the military spectrum, from conventional and highly trained to unconventional and poorly equipped. In addition, it is possible for the warlord to have access to a number of armed forces varying from soldiers-turned-rebels or 'sobels' to armed gangs. ${ }^{52}$ In practice, many African warlords have weak military capabilities. They are unable to engage in open combat with other armed groups (including competing warlords) and, instead, tend to focus their violence at local, civilian populations. ${ }^{53}$ Herein lies the potential for the warlord to utilise high qualities of violence, including the use of terror, in the absence of their ability to use high quantities of force.

Through these three factors - resource type, civilian interaction, and military capabilities - we can deduce that the variation in type and nature of warlord violence is (at least conceptually) incredibly mixed. While all warlords must use violence in order to retain their position, a great number of intervening factors affect how violence is actually conducted. Indeed, in situations of varied local factors, the same warlord's use of force is likely to change over time.

To summarise, by definition, the warlord must reflect an organisation that combines military and political power, in which the warlord himself is central, and which seeks control over a geographically defined space that is independent from the state. While the warlord may, in effect, undermine the state in the area under his control, he does not seek state or national position. Rather, he desires autonomy and independence as a means to access economic resources and 
control the local population. In general, the extent of a warlord's independence from a state and society varies according to the relative size, military capabilities, and wealth of the warlord organisation. Combined, the resources the warlord seeks to control, and the nature of his relations to the local population (and the state), dictate the nature and levels of violence the warlord uses. What is conceptually important is that the nature of the warlord's power, which combines the military and the political, requires the perpetual use or threat of violence. Furthermore, warlordism as a phenomenon can vary significantly and should be placed on a continuum: from limited formations based at the very local level and with limited capacities, to extensive regional structures that wield power on the basis of military power and personal charisma. As a result, warlordism can manifest in forms of gangsterism, at the one end of the scale, to regional protonationalist movements at the other end. ${ }^{54}$ Of course, over time and circumstance, a small-scale warlord may come to operate on a much larger basis, and vice versa.

\section{Common warlord characteristics}

African warlords are commonly regarded to be lacking popular legitimacy and support, and as using excessive violence. In fact, neither of these characteristics is necessary. There is sufficient variation within the very concept of the warlord that they can be either illegitimate or (at least partly) legitimate, and they can use excessive, irrational violence, or require low levels of (rational) violence. This variation is conceptually consistent. These commonly noted, but not necessary, elements of warlordism have come to shape the popular, negative narrative of African warlords.

\section{The warlord's legitimacy}

First, warlords are commonly seen to be illegitimate. This occurs where warlords control the local population through fear and coercion, often involving 'barbaric' or excessive forms of violence (as discussed below). The warlord is unable to gain, and does not seek, legitimacy among the populations that live in the region under his control. ${ }^{55}$ It is indisputably the case that, by definition, warlords do not require popular legitimacy to exist. Indeed, warlord organisations often take advantage of local civilians to the same extent that they take advantage of any other group, since they do not depend on them for support. ${ }^{56}$ Their very organisational structure makes them autonomous from the state and enables autonomy from the local population. However, this does not mean that, in some cases, warlords do not come to have popular legitimacy. Warlords can provide an alternative social structure to the state, one that is consistent with the customs, needs, and desires of the local populations. Indeed, warlords may provide security and other public goods that are superior to those of the state. ${ }^{57}$ Through the establishment of these mutually beneficial transactional relations, the warlord can come to gain local legitimacy. Writing about the experience of warlords in Tajikistan, Nourzhanov writes, '[a] warlord... is not a mere bandit or selfish 
politician with an organised military force. A warlord is a protector and provider who is accepted by a community... as a legitimate leader'. ${ }^{58}$ It is entirely possible for the warlord to develop legitimate alternatives to the state, which are preferred by the local population.

In sum, there can be significant variation within the warlord organisation and its societal ties, which mean its levels of potential legitimacy can vary greatly. ${ }^{59}$ The salient point is that warlords, by virtue of their organisational structure and means of political power, do not require local popular support, but may attain it due to other reasons.

\section{The warlord as excessively violent}

Second, warlords are often associated with excessive and particularly cruel uses of force. The 'warlord way of warfare' is typified by its extreme use of violence, which often elicits fear and targets civilians. There is an inclination to use terror and other forms of systematic violence to preserve power relations. These 'senseless' methods of violence inflict great suffering on civilian victims for seemingly futile reasons. ${ }^{60}$ This results in the fragmentation of society, high levels of civilian victimisation, and the creation and perpetuation of a violent society.

While it is undeniable that the warlord, by virtue of deriving political position from military power, requires the continual use of violence, it does not follow that this violence must be excessively savage. Indeed, in cases where the warlord develops a 'protostate', brutal violence in abundance would seem both unnecessary and irrational. In other contexts, the warlord may require continual violence and a lack of civil order to maintain their stronghold. While violence may be ruthless, it is not necessarily irrational. Violent acts such as mutilations ranging from severed noses, lips, and fingers to messages carved on different body parts are politically symbolic. ${ }^{61}$ The warlord organisation is able to through the use of limited, if grotesque force - display a political message; for example, to deter locals from participating in elections or other government processes. These kinds of violence reflect the military position of the warlord. By virtue of the organisation's often militarily weak, ill-experienced, and illdisciplined power, it adopts unconventional methods of force. This violence, while graphic, may in fact be limited. It aims to create maximum impact with minimum use of force in order to maintain the dominance of the warlord.

As we can see from this conceptual discussion, depicting warlords as lacking popular legitimacy and as utilising irrational violence fails to account for variation within the actor. By definition, warlords seek autonomy from the state and do not require local support to do this. They do need local means of coercion to be able to overpower competing groups militarily and politically, for which violence is typically used. However, it does not follow that warlords are necessarily illegitimate or use excessive force. 


\section{Our current (mis)understanding of the African warlord}

Despite the conceptual misgivings, 'warlord' has come to be applied to African ${ }^{62}$ armed groups who are deemed to lack popular support and who use 'barbaric' violence. In this way, non-essential characteristics of the warlord have come to be emphasised and essential components have been sidelined. This has led to two, somewhat unintuitive yet simultaneous trends. On the one hand, it has led to a narrow and negative interpretation of the warlord - as harmful to society and politics. On the other hand, 'warlord' has come to be applied too broadly, with a variety of rebel actors being given the title. To some extent, this has transpired as part of a wider move to describe African wars as illegitimate and greed-induced. It has also arisen because of notions of the high-capacity warlord from 'above' from the state level rather than the local context. In collection, this has degraded the meaning of the term 'warlord' itself. I will now briefly show how the African warlord has come to be viewed in a skewed and biased way, and make efforts to explore why this pattern is problematic.

\section{Current definitions - too loose and too narrow}

Current conceptualisations of the African warlord fail to distinguish warlords from other rebel actors. For example, the often assigned 'warlord' Sierra Leonean RUF - while seen as illegitimate, lacking ideology, and using excessive force desired and aggressively sought state power. With strong assistance from Liberia's then-president, Charles Taylor, the RUF sought to usurp the state. In this regard, Foday Sankoh or the RUF cannot be conceived as 'warlord'. Similarly, Joseph Kony and the LRA have been designated as 'warlord' where they are more accurately rebel or insurgent (or some form of hybrid). As with the RUF, literature on the LRA has focused on their 'methods of violence', which has involved the grotesque and vivid use of force. ${ }^{63}$ Once more, it was the analysis of the groups as lacking legitimacy and using unwarranted violence that led to the designation of 'warlord'. This dilutes the warlord to meaning something like 'illegitimate and violent rebel' or even 'barbaric thug'. Yet, warlords are distinguished from rebels because they do not seek state power. By ignoring this, the term takes on a judgemental position rather than an analytical one.

Furthermore, this kind of conceptualisation ignores the possibility that warlord and insurgent structures may coexist and interact - for example, a warlord organisation may finance a rebellion. The possibility of this coexistence - of warlords and rebels working symbiotically - remains under-researched. ${ }^{64}$ And yet, just as we know the state may align with warlord groups, ${ }^{65}$ it is possible for rebels or other non-state groups to do the same. One interesting case comes from KwaZulu-Natal during South Africa's transition period in the 1990s. While warlordism is most commonly associated with the Inkatha Freedom Party (IFP) (who were often supported by the apartheid state), Mathis points out that the African National Congress (ANC), fearing their loosening influence in the region, came to associate with and recruit warlords. ${ }^{66}$ An alliance of the ANC 
to local warlords became mutually beneficial: the ANC was able to maintain influence and the warlords were able to gain power locally. In other circumstances, it is possible for rebel organisations to actually transition into warlord groups and vice versa. Rebel organisations with weak military positions whose political aims are unattainable may fall to warlordism in order to secure income and local power. The LRA may be a good case in point. Conversely, warlords who come to see benefits in state-level power - be it because peace has become imminent or broader personal aims - may become rebels or politicians.

Similarly, it is not helpful to conceive of warlords narrowly - as solely negative actors of political violence. They can arise and come to have multiple effects on society - both positive and negative. Defining warlords as purely negative places judgements on the actors before any real analysis has taken place. It fails to force analytical questions such as: How does the nature of the state create conditions for warlordism to occur? Can warlords offer an alternative to the state? Is warlordism a necessary part of state formation in Africa? Can we conceive of warlords, in some cases, as regionally or locally legitimate? Moreover, it ignores the weak position of many African states. Thus, any conception of warlordism needs to allow for variation. This suggestion is not novel; Jackson in particular has presented the potentially positive effects and contributions of warlords. He argues that warlords should be seen as an alternative form of governance and not as the irrational anarchists that scholars depict. ${ }^{67}$ For example, 'local warlord' Mayi Mayi groups of eastern Democratic Republic of Congo are a reflection of the context of a disintegrating state and insecurity in an increasingly militarised area. Warlords at the local level (often called 'strongmen') can offer alternative means of political access for otherwise marginalised groups. ${ }^{68}$

Similarly, Wantchekon works to dispel the notion that the emergence of warlords will lead to the perpetuation of war and an absence of peace. He argues that 'intelligent' warlords - those who act to preserve their own interests - will seek peace over war when conditions dictate that this course is most beneficial. ${ }^{69}$ Wantchekon's theoretically persuasive work importantly challenges the notion that warlords require the disintegration of the state. Indeed, he contends that when war becomes a stalemate and starts to hinder the warlord economically, he will opt for peace and state reintegration. These 'intelligent' warlords recognise the benefits of peace, and therefore, peace can emerge from anarchy. In this way, warlords show themselves to not lead to the eternal and spiralling degradation of the state and society, as is most commonly presented. This thinking also shows the mechanisms by which warlords may transition into politicians. However, this type of analysis remains on the periphery of discourse regarding African warlords.

\section{African warlordism and 'new wars' - a Western bias}

The broad and overwhelmingly negative application and interpretation of the African warlord relates to wider movements in academic literature on rebellion 
on the continent. Warlords are seen as the archetypal actors in the 'new' wars (post-Cold War) literature. They are typified as being motivated by selfish greed, lacking ideology, perpetuating the continual use of violence, and completely illegitimate. ${ }^{70}$ Supporting this intellectual movement is quantitative analysis of civil wars in Africa, which, roughly speaking, depicts rebels as motivated primarily by greed. ${ }^{71}$ This type of analysis has typified the study of warlordism in Africa. ${ }^{72}$ In this way, 'warlord' is a loaded term with pejorative connotations such as illegitimate, coercive, and savage.

Warlords are seen to 'offend the basic precepts of Western liberalism', as actors willing and able to ignore the rule of law. ${ }^{73}$ The international community and academics tend to be biased in their analysis of warlords because, despite the nature of the African state, international relations and political analysis exists predominantly at the state level. ${ }^{74}$ There is an inflexibility in analysing other forms of power and politics. In effect, non-state forms become, de facto, illegitimate. Ahram and King argue 'the normative thicket created by assuming that states alone enjoys a monopoly over the use of force' limits our ability to examine non-state violent actors. Indeed, they make clear that such actors regardless of their other features - are 'dismissed with opprobrium' ${ }^{75}$ Relatedly, this illustrates the tendency to focus on charismatic and state-challenging characters such as Charles Taylor, Foday Sankoh, or Joseph Kony, which has skewed study from the local to the state level.

Reflecting this wider bias, Hills wryly argues that a warlord is not a warlord 'When he's pro-Western' ${ }^{76}$ Indeed, on occasion, the West has co-opted or otherwise legitimised the African warlord. The UN in Somalia in the early 1990s, for example, chose to negotiate with Mogadishu warlords (who held military power) rather than local clan leaders (who had political legitimacy). A reflection of societal misunderstandings by US commanders, this had the disastrous result of giving political legitimacy to warlords over and above local, established mechanisms of authority. ${ }^{77}$ More recently, we have seen this occur in Libya, where NATO supported anti-Gaddafi strongmen. ${ }^{78}$ Importantly, these actors become legitimised 'from above', at the international level, and not necessarily at the local level.

\section{The economic elements of warlordism have been overemphasised}

Within the literature, there has been a tendency to stress the international market or economic capacities of the warlord, in particular to connect the warlord to organised criminal networks. This has skewed our understanding of warlords in several ways, not least because it leads to conceptualisations of the warlords as unconnected and entirely illegitimate in their regional or national context. This typology has unhelpfully removed the possibility of warlords having communitarian connections. $^{79}$

Robinson, for example, argues that, by definition, warlords must be 'motivated [solely] by narrow, commercial self-interest'. ${ }^{80}$ Nourzhanov argues 
this approach is overly restrictive, instead suggesting that warlords can act in the interest of communities as well as egoistically. ${ }^{81}$ Robinson appears to conflate the state and society: while the warlord requires the disintegration of the state (at least in some respects) in order to exist, it does not necessarily follow that he requires the disintegration of society, or that state and societal disintegration are necessarily linked. Similarly, Vinci hints that the common typology of warlords as 'businessmen of war' may have been overstated. ${ }^{82}$ I take this position more strongly. While the warlord clearly needs access to economic resources, it is not necessarily the case that the warlord's initial and primary motives are personal enrichment. Indeed, the case of South Africa suggests that maintaining traditional power dynamics was central to warlord formations. ${ }^{83}$ Thus, while economic accumulation is important to many warlords, it is not necessarily the only or most important explanation of warlord behaviour. Economic explanations of warlordism are just one set of causes of the phenomenon. ${ }^{84}$

\section{Conclusion}

So, has the African warlord disappeared? Our warlords of the 1990s have had mixed outcomes: many have died, some have become politicians, others have become rebel leaders, and some - notably in the DRC - have remained. Where transition has occurred, this is often a reflection of changing national circumstances: South Africa stabilised from the mid-1990s; conflict in Somalia has changed in nature; Sierra Leone and Liberia have become peaceful. However, preconditions for warlordism - uneven state authority and the existence of ungoverned spaces - exist in many states today, for example: Central African Republic, Mali, Sudan and South Sudan, and Libya. In these and other states, more conditions exist: for example, politics is regionalised or based on the inclusion and exclusion of certain groups; national military forces are weak and poorly organised; the provision of public goods and services is unequal; access to national resources is poorly managed; and unemployment, especially among the youth, remains high. In this way, the potential for warlordism is ever present.

Rather, what is clear is that the model of warlordism that developed from the 1990 s is unhelpful in certain ways. It generated an overwhelmingly negative perception of warlordism on the continent, where there should, in fact, be space to examine potential positive impacts of warlord organisations or to recognise the contexts in which warlord groups arise. Rather, warlords are confused with other types of non-state violent actors - in particular rebels - and have come to typify illegitimate, clandestine, and brutal challenges to state power. I have argued here that we need to be more disciplined in our designation. By focusing on definitionally required components of warlordism, rather than common (but not necessary) behavioural traits, we can come to have more accurate and analytically fruitful study of the phenomenon. This will clear the way for questions of pertinence to be asked, such as: Who is a modern African warlord? How can warlord organisations come to operate as a sub-group of a rebel 
organisation? And do warlords provide alternative forms of governance in the context of a anarchy?

\section{Acknowledgements}

I would like to thank Eric Dêlidji Degila, Adegbenga Isaac Aladegbola, Carlos Shenga, Ashleigh Searle, Guy Lamb, and Markus Korhonen for comments on drafts of this article. Thanks also to Karusha Naidoo for her research assistant work.

\section{Disclosure statement}

No potential conflict of interest was reported by the author.

\section{Notes}

1. This special issue aimed to question whether 'warlord' was an applicable term for Africa. In it, Roberts argued that the term was applicable to the African context given, 'the decay of nationalism into regionalism and sectarianism; the extent to which such provincial power centres link up with foreign interests; the disintegration of the military hierarchy and the rise of lower-ranked officer strata; and the burdens imposed on civil society by the extortion and violence occasioned by warlordism and by the obstacles it places in the way of political solutions to problems'. See Roberts, 'Warlordism in China', 26. Similarly, Charlton and May argue that the 'warlord model' is most useful to explaining the collapse of the state and rise of regional centres of power in Chad. See Charlton and May, 'Warlords and Militarism in Chad' $17-24$.

2. Robinson, 'Twenty-First Century Warlords', 121; Hills, 'Warlords, Militia and Conflict', 39; Vinci, 'Like Worms', 314; Ahram and King, 'The Warlord as Arbitrageur', 169-170.

3. Giustozzi, 'Respectable Warlords?', 7; Jackson, 'Warlords as Alternative Forms of Governance', 134; Rich, 'Warlords, State Fragmentation', 82, 88.

4. Robinson, 'Twenty-First Century Warlords', 128.

5. Tilly, Formation of National States, 42.

6. See, for example: Sheridan, Chinese Warlord; Rich, 'Warlords, State Fragmentation', 80-82; MacKinlay, 'Defining Warlords', 50-52; Marten, 'Warlordism in Comparative Perspective', 50-52.

7. Giustozzi, 'Respectable Warlords?'; Stanski, 'So These Folks are Aggressive'; Nourzhanov, 'Saviours of the Nation or Robber Barons?'; Jackson, 'Warlords as Alternative Forms of Governance'.

8. In order, MacKinlay, 'War Lords', 24; Vinci, 'Like Worms'; Peters, 'The New Warrior Class', 19; MacKinlay, 'Defining Warlords', 55.

9. See, for example, Robinson, 'Twenty-First Century Warlords'; MacKinlay, 'Defining Warlords'.

10. Rich, 'Warlords, State Fragmentation', 84.

11. Skaperdas, 'Warlord Competition', 440-441.

12. The accepted ballpark number being 1000 fatalities over the course of a civil war, with an average of at least 100 per year.

13. See Vinci, 'Like Worms', 318.

14. Young, The African Colonial State, 26-31.

15. Szeftel, 'Warlords and Problems of Democracy'.

16. Giustozzi, 'The Debate on Warlordism', 15.

17. Charlton and May, 'Warlords and Militarism in Chad', 17. 
18. Hills, 'Warlords, Militia and Conflict', 35-36.

19. Ahram and King, 'The Warlord as Arbitrageur', 173.

20. Rich, Warlords in International Relations.

21. MacKinlay, 'Defining Warlords', 55; Reno, Warfare in Independent Africa, 167.

22. MacKinlay, 'Defining Warlords'.

23. Lezhnev, Crafting Peace, 3.

24. MacKinlay, 'Defining Warlords': 48, 58.

25. Rich, 'Warlords, State Fragmentation', 90.

26. Marten, 'Warlordism in Comparative Perspective', 47-48.

27. Vinci, 'Like Worms', 321-322.

28. Barnes and Hassan, 'The Rise and Fall of Mogadishu's Islamic Courts', 152.

29. Robinson, 'Twenty-First Century Warlords', 143.

30. Marten, 'Warlordism in Comparative Perspective', 58.

31. Vinci, 'Like Worms', 321; Rich, 'Warlords, State Fragmentation', 88.

32. Jackson, 'Warlords as Alternative Forms of Governance', 138.

33. Ibid., 147.

34. Charlton and May, 'Warlords and Militarism in Chad', 17.

35. African states have been known to 'subcontract organised violence' to warlords who have the ability to control a disorderly border region, control migration beyond the city, and who can protect a boundary or threaten a potential enemy on the other side of the border. See Ahram and King, 'The Warlord as Arbitrageur', 172-3. For example, Inkatha warlords in South Africa, who threatened the ANC, were supported by the apartheid state. See Mathis, 'From Warlords to Freedom Fighters', 433.

36. Giustozzi, 'Respectable Warlords?', 3.

37. Marten, 'Warlordism in Comparative Perspective', 47.

38. For example, Harris writes: 'Given the international reputation of Taylor as a brutal warlord whose sole aim had never wavered from the capture of power in Monrovia [i.e. state power]...' (emphasis added), see 'From "Warlord" to "Democratic" President', 431. I highlight Harris here not to individually point him out, but to indicate a wider acceptance in the literature that has sidelined the vital characteristic of warlords, specifically, their independence from the state. References or allusions to Charles Taylor as a warlord are common; even Robinson and MacKinlay, in pieces that explicitly aim at defining the warlord, include him in their conception. See Robinson, 'Twenty-First Century Warlords', 125; and MacKinlay, 'Defining Warlords' and 'War Lords'. And yet, logically, the point seems obvious: a character who relies on the disintegration of the state cannot then come to desire its (re) integration without becoming something qualitatively different.

39. Marten, 'Warlordism in Comparative Perspective', 46-47.

40. Giustozzi, 'Respectable Warlords?', 2.

41. Vinci, 'An Analysis and comparison of armed groups in Somalia', 82.

42. Ahram and King, 'The Warlord as Arbitrageur', 172-3.

43. Ibid., 173.

44. MacKinlay, 'Defining Warlords', 54.

45. Duffield, 'Post-Modern Conflict'.

46. Jackson, 'Warlords as Alternative Forms of Governance', 147-148.

47. Skaperdas, 'Warlord Competition', 440-441. Skaperdas also lays out why bargaining towards 'armed peace' is inherently difficult for warlords. As in Hobbes's state of nature, Skaperdas points out that without a higher authority, it is impossible for warlords to enforce contracts between themselves. This leads to a propensity towards violence and increasingly arming as the only means by which to show superiority. See 'Warlord Competition', 441-444. 
48. Giustozzi, 'Respectable Warlords?', 2; Jackson, 'Warlords as Alternative Forms of Governance', 138, 148.

49. Skaperdas, 'Warlord Competition', 436.

50. Giustozzi, 'Respectable Warlords?', 2-3.

51. Skaperdas, 'Warlord Competition'.

52. Jackson, 'Warlords as Alternative Forms of Governance', 141-142.

53. MacKinlay, 'Defining Warlords', 55, 57.

54. Rich, Warlords in International Relations, 4-5.

55. MacKinlay, 'Defining Warlords'.

56. Vinci, 'Like Worms', 320, 327.

57. Ahram and King, 'The Warlord as Arbitrageur', 173.

58. Nourzhanov, 'Saviours of the Nation or Robber Barons?', 126.

59. It is worth noting that any warlord's 'legitimacy' will be necessarily restricted or limited to the locale. The warlord organisation is unlikely to be legitimised by the state as they operate autonomously from it, and because a state endorsement would be self-undermining (for both the state and the warlord).

60. Vinci, 'Like Worms', 317, 324; Rich, 'Warlords, State Fragmentation', 85.

61. Richards, 'New Political Violence in Africa', 436-437.

62. In current parlance, warlord is applied overwhelmingly to Africans. It is also used to describe some actors in Afghanistan (see Giustozzi, 'Respectable Warlords?'; and Stanski, 'So These Folks are Aggressive'), Tajikistan (see Nourzhanov, 'Saviours of the Nation or Robber Barons?'), and, occasionally in Latin America, most commonly, Colombia (see Jones, 'Parainstitutional Violence').

63. Vinci, 'The Strategic Use of Fear', 369-373.

64. Reno alludes to the potential relations of warlords to other rebel and state groups. As he puts it, '[t]hese interlocking relationships produce very complex conflicts'; see Warfare in Independent Africa, 165. Reno asserts that so-called 'parochial rebels' those who arm local networks based on local identity - are likely to partner with warlord organisations. Similarly, Lezhnev suggests that 'partial warlord groups' or 'ethno-warlords' may come to exist and have warlord components; see Crafting Peace, $12-13$. It is clearly necessary for more research to take place to unpack the workings dynamics of these potential interlinkages. It will be important to maintain that while rebel movements can become warlord organisations, and warlord organisations can become rebel movements, and rebel movements may have warlords attached to them, warlords and rebels are conceptually separate entities.

65. See note 35 .

66. Mathis, 'From Warlords to Freedom Fighters', 424. Mathis notes two prominent ANC-affiliated warlords - Sipho Mkhize and Mkhandi Shozi - who 'acted openly as warlords for most of the 1980s and then were either killed or driven into partial hiding in the 1990s'; see 'From Warlords to Freedom Fighters', 432.

67. Jackson, 'Warlords as Alternative Forms of Governance', 132.

68. Vlassenroot and van Acker, 'War as Exist from Exclusion?', 55-56.

69. Wantchekon, 'The Paradox of "Warlord" Democracy'. Similarly, Giustozzi has attempted to show the positive impacts of 'enlightened' warlords in Afghanistan, arguing that warlords have the potential to gain legitimacy from the state and become enveloped within central administration (and thus transition from warlord to regional leader or politician). See Giustozzi, 'Respectable Warlords?'.

70. Broadly speaking, the new wars literature posits that while old civil wars were motivated by communal grievance, private loot incentivises new wars. Where old wars garnered broad support, new wars lack such popularity (or at least do not require it). Proponents argue that whereas old wars had controlled violence, new wars involve unwarranted levels of violence. Both government and rebels are 
depicted as thugs who use violence and unconventional warfare for personal gain. Clearly, within this distinction, old wars are seen as legitimate and justified, new wars as illegitimate and unjustified. Differences as outlined by Kalyvas, "New" and "Old" Civil Wars', 101-102. For greater detail, see Kaldor, 'Old Wars, Cold Wars, New Wars, and the War on Terror'; Mueller, 'Policing the Remnants of War'.

71. Collier and Hoeffler's work has been most influential in this regard. Their regression analysis categorises rebels as motivated either by grievance or by greed. Through their proxy measures for these categories, they find much stronger correlation between rebellion and greed. Collier and Hoeffler argue that it is not political grievance or even political control over territory rebels seek to gain. Instead, unconventional force is used as a means to gain and secure resource-rich areas, which the insurgents can then pillage. Importantly, this means rebels may have no inclination to engage in fighting with government forces and no desire to gain political power. See Collier and Hoeffler, 'Greed and Grievance'. Opponents to this body of work argue that their analysis and conclusions are incorrectly skewed to economic explanations. For example, Mkandawire notes that, in Africa, no known insurgent movement has transformed from criminal networks who extend to rebels in order to accrue economies of scale. See Mkandawire, 'The Terrible Toll', 187-188. Similarly, Kalyvas has pointed out the unnecessary dichotomy in Collier and Hoeffler's depiction of rebels as either greedy or aggrieved. See Kalyvas, "New" and "Old" Civil Wars", 102.

72. Vinci, 'Like Worms', 313-314.

73. Rich, 'Warlords, State Fragmentation', 78.

74. MacKinlay, 'War Lords', 26.

75. Ahram and King, 'The Warlord as Arbitrageur', 170.

76. Hills, 'Warlords, Militia and Conflict', 36. In the case of Afghanistan, this distinction is clear. 'Afghan warlords' in the north who were anti-Taliban were heralded by the United States (who often changed their title to 'local commanders' or 'militia leaders'). See Stanski, 'So These Folks are Aggressive', 73-74.

77. For more see, Lewis, 'Misunderstanding the Somali Crisis'; Stevenson, 'Hope Restored in Somalia?'.

78. Amin, 'An Imperialist Springtime?'.

79. Henriksen and Vinci, 'Combat Motivation', 102.

80. Robinson, 'Twenty-First Century Warlords', 125.

81. Nourzhanov, 'Saviours of the Nation or Robber Barons?', 110.

82. Vinci, 'Like Worms'. Vinci points out that economic accumulation is a means to maintain patronage networks and, consequently, warlord power. In this way, looting and other forms of accumulation is an essential component of the warlord organisation behaviour because it helps maintain it. It does not necessarily follow that the primary or only means of warlord existence is for personal enrichment.

83. Morris and Hindson, 'South Africa: Political Violence'.

84. Ahram and King, 'The Warlord as Arbitrageur', 173.

\section{Bibliography}

Ahram, Ariel and Charles King. 'The Warlord as Arbitrageur'. Theory \& Society 41 (2012): 169-86.

Amin, Samir. 'An Imperialist Springtime? Libya, Syria, and Beyond'. Samir Amin interviewed by Aijaz Ahmad. MRzine, 24 April 2012. Available at: http://mrzine. monthlyreview.org/ (accessed 30 November 2014).

Barnes, Cedric and Harun Hassan. 'The Rise and Fall of Mogadishu's Islamic Courts'. Journal of Eastern African Studies 1, no. 2 (2007): 151-60. 
Buzan, Barry. People, States and Fear. London: Harvester Wheatsheaf, 1991.

Charlton, Roger and Roy May. 'Warlords and Militarism in Chad'. Review of African Political Economy, no. 45/46 (1989): 12-25.

Collier, Paul and Anke Hoeffler. 'Greed and Grievance in Civil War'. Oxford Economic Papers 56 (2004): 563-95.

Duffield, Mark. 'Post-Modern Conflict: Warlords, Post-Adjustment States and Private Protection'. Civil Wars 1, no. 1 (1998): 65-102.

Giustozzi, Antonio. 'The Debate on Warlordism: The Importance of Military Legitimacy'. Crisis States Research Centre Discussion Paper no. 13. London: Crisis States Research Centre, LSE, 2005.

Giustozzi, Antonio. 'Respectable Warlords? The Politics of State-Building in PostTaleban Afghanistan'. Crisis States Research Centre Working Paper no. 33. London: Crisis States Research Centre, LSE, 2003.

Harris, David. 'From "Warlord" to "Democratic" President: How Charles Taylor Won the 1997 Liberian Elections'. Journal of Modern African Studies 37, no. 1 (1999): 431-55.

Henriksen, Rune and Anthony Vinci. 'Combat Motivation in Non-State Armed Groups'. Terrorism and Political Violence 20, no. 1 (2007): 87-109.

Hills, Alice. 'Warlords, Militia and Conflict in Contemporary Africa: A Re-Examination of Terms'. Small Wars \& Insurgencies 8, no. 1 (1997): 35-51.

Jackson, Paul. 'Warlords as Alternative Forms of Governance'. Small Wars \& Insurgencies 14, no. 2 (2003): 131-50.

Jones, Adam. 'Parainstitutional Violence in Latin America'. Latin American Politics and Society 46, no. 4 (2004): 127-48.

Kaldor, Mary. 'Old Wars, Cold Wars, New Wars, and the War on Terror'. Lecture given to the Cold War Studies Centre, London School of Economics, February, 2005.

Kalyvas, Stathis. "'New” and "Old" Civil Wars: A Valid Distinction?' World Politics 54, no. 1 (2001): 99-118.

Lewis, I.M. 'Misunderstanding the Somali Crisis'. Anthropology Today 9, no. 4 (1993): $1-3$.

Lezhnev, Sasha. Crafting Peace: Strategies to Deal with Warlords in Collapsing States. Plymouth, UK: Lexington Books, 2005.

MacKinlay, John. 'Defining Warlords'. International Peacekeeping 7, no. 1 (2000): 48-62.

MacKinlay, John. 'War Lords'. The RUSI Journal 143, no. 2 (1998): 24-32.

Marten, Kimberley. 'Warlordism in Comparative Perspective'. International Security 31, no. 3 (2006/2007): 41-73.

Mathis, Sarah. 'From Warlords to Freedom Fighters: Political Violence and State Formation in Umbumbulu, South Africa'. African Affairs 112, no. 448 (2013): 421-39.

Mkandawire, Thandika. "The Terrible Toll of Post-Colonial "Rebel Movements" in Africa: Towards an Explanation of the Violence against the Peasantry'. The Journal of Modern African Studies 40, no. 2 (2002): 181-215.

Morris, Mike and Doug Hindson. 'South Africa: Political Violence, Reform and Reconstruction'. Review of African Political Economy, no. 53 (1992): 43-59.

Mueller, John. 'Policing the Remnants of War'. Journal of Peace Research 40, no. 5 (2003): 507-18.

Nourzhanov, Kirill. 'Saviours of the Nation or Robber Barons? Warlord Politics in Tajikistan'. Central Asian Survey 24, no. 2 (2005): 109-30.

Peters, Ralph. 'The New Warrior Class Revisited'. Small Wars \& Insurgencies 13, no. 2 (2002): 16-25. 
Reno, William. Warfare in Independent Africa. New York: Cambridge University Press, 2011.

Reno, William. Warlord Politics and African States. London: Lynne Rienner, 1998.

Rich, Paul. Warlords in International Relations. Basingstoke, UK: MacMillan Press, 1999.

Rich, Paul. 'Warlords, State Fragmentation and the Dilemma of Humanitarian Intervention'. Small Wars \& Insurgencies 10, no. 1 (1999): 78-96.

Richards, Paul. 'New Political Violence in Africa: Secular Sectarianism in Sierra Leone'. GeoJournal 47 (1999): 433-42.

Roberts, J.A.G. 'Warlordism in China'. Review of African Political Economy, no. 45/46 (1989): 26-33.

Robinson, T.P. 'Twenty-First Century Warlords: Diagnosis and Treatment?' Defence Studies 1, no. 1 (2001): 121-45.

Sheridan, James E. Chinese Warlord: The Career of Feng Yu-hsian. Stanford, CA: Stanford University Press, 1966.

Skaperdas, Stergios. 'Warlord Competition'. Journal of Peace Research 39, no. 4 (2002): 435-46.

Stanski, Keith. "“So These Folks Are Aggressive": An Orientalist Reading of "Afghan Warlords"'. Security Dialogue 40, no. 1 (2009): 73-94.

Stevenson, Jonathan. “"Hope Restored in Somalia?”. Foreign Policy, no. 91 (1993): $138-54$.

Szeftel, Morris. 'Editorial: Warlords and Problems of Democracy in Africa'. Review of African Political Economy, no. 45/46 (1989): 3-11.

Tilly, Charles. The Formation of National States in Western Europe. Princeton, NJ: Princeton University Press, 1975.

Vinci, Anthony. 'An Analysis and Comparison of Armed Groups in Somalia'. African Security Review 15, no. 1 (2006): 76-90.

Vinci, Anthony. "Like Worms in the Entrails of a Natural Man": A Conceptual Analysis of Warlords'. Review of African Political Economy 34, no. 112 (2007): 313-31.

Vinci, Anthony. 'The Strategic Use of Fear by the Lord's Resistance Army'. Small Wars \& Insurgencies 16, no. 3 (2005): 360-81.

Vlassenroot, Koen and Frank van Acker. 'War as Exit from Exclusion? The Formation of Mayi Mayi Militias in Eastern Congo'. Afrika Focus 17, nos. 1-2 (2001): 51-77.

Wantchekon, Leonard. 'The Paradox of "Warlord" Democracy: A Theoretical Investigation'. American Political Science Review 98, no. 1 (2004): 17-33.

Young, Crawford. The African Colonial State in Comparative Perspective. New Haven, CT: Yale University Press, 1994. 